\title{
HTLV-1 HBZ protein inhibits IRF3-mediated innate immune responses
}

\author{
Renée N Douville ${ }^{1 *}$, Stéphanie Olière ${ }^{1}$, Patrick L Green ${ }^{2}$, Rongtuan Lin ${ }^{1}$, John Hiscott ${ }^{1,3}$ \\ From 15th International Conference on Human Retroviruses: HTLV and Related Viruses \\ Leuven and Gembloux, Belgium. 5-8 June 2011
}

The bZIP factor (HBZ) is an HTLV-1 regulatory protein encoded by anti-sense transcription of the HTLV-1 genome. HBZ mRNA expression correlates with clinical disability in HAM/TSP patients - and can be reversed by interferon (IFN) therapy. Sporadic evidence suggests that HBZ may have a negative role on interferon signalling. Activation of IRF3-dependent IFN signalling either direct induction of IFN $\beta$, viral restriction factors or interferon stimulated genes (ISGs) - is crucial for TLR and RLR mediated antiviral response. Thus, we sought to determine whether HBZ can impair IRF3mediated innate immune responses. Over-expression of active forms of RIG-I, MAVS, TBK1, IKK $\varepsilon$ or IRF3 alone drive an antiviral response - however, in the presence of an HBZ expression vector, IFN $\beta$ responses were abrogated by $50-70 \%$. In contrast, HBZ enhanced IRF7-dependent responses. In confirmation, both PBMC and human astrocytes transfected with HBZ and subsequently stimulated with IFN-triggering ligands (LPS, PolyI:C, VSV, Sendai virus and HTLV-1 virions), exhibited impaired IRF3-dependent signalling as compared with controls. As IRF3 is known to bind other bZIP proteins, further studies are underway to delineate the nature of IRF-HBZ interactions. Identifying such a mechanism may explain an enhanced risk of neurologic infection, as we show that chronically HTLV-1 infected astrocytes gradually increase and maintain long-term HBZ expression. Defining the immunomodulatory properties of HTLV-1 HBZ protein will provide a vital contribution toward understanding clinical outcome and risk of opportunistic infection associated with HTLV-1 infection.

\footnotetext{
* Correspondence: renee.douville@gmail.com

'Dept. of Medicine, McGill University / Lady Davis Institute, Montreal,

Quebec, Canada H3T 1E2

Full list of author information is available at the end of the article
}

\section{Author details}

${ }^{1}$ Dept. of Medicine, McGill University / Lady Davis Institute, Montreal, Quebec, Canada H3T 1E2. ${ }^{2}$ Dept. of Veterinary Biosciences, Ohio State University, Columbus, Ohio, 43210, USA. ${ }^{3}$ Vaccine and Gene Therapy Institute - Florida, Port St. Lucie, Florida, 34987, USA.

Published: 6 June 2011

\section{doi:10.1186/1742-4690-8-S1-A99}

Cite this article as: Douville et al: HTLV-1 HBZ protein inhibits IRF3mediated innate immune responses. Retrovirology 2011 8(Suppl 1):A99.
Submit your next manuscript to BioMed Central and take full advantage of:

- Convenient online submission

- Thorough peer review

- No space constraints or color figure charges

- Immediate publication on acceptance

- Inclusion in PubMed, CAS, Scopus and Google Scholar

- Research which is freely available for redistribution
() Bïomed Central

\section{Biomed Central}

